\title{
Houm Plant Extract (Ephedra), An Iranian Traditional Remedy for Insulin Resistance
}

\author{
Houm Bitki Özü (Ephedra), İnsülin Direnci için İranlı Geleneksel Bir İlaç
}

\section{Elham Ehrampoush ${ }^{1,2}$, Amin Koohpayeh ${ }^{1}$, Noushid Zare ${ }^{3}$, Layla Shojaie ${ }^{4}$, Reza Homayounfar ${ }^{1,2}$, Amin Almasi $^{1}$} Saied Taghizade ${ }^{1}$, Reza Alipoor ${ }^{5}$

\footnotetext{
${ }^{1}$ Noncommunicable Diseases Research Center, Fasa University of Medical Sciences, Fasa, Iran

${ }^{2}$ Nutrition Department, Fasa University of Medical Sciences, Fasa, Iran

${ }^{3}$ Faculty of Pharmacy, International Campus, Tehran University of Medical Science, Tehran, Iran

${ }^{4}$ Student Research Committee, Tehran University of Medical Sciences, Tehran, Iran

${ }^{5}$ Student Research Committee, Hormozgan University of Medical Sciences, Bandar Abbas, Iran
}

\section{ABSTRACT}

Objectives: Houm plant (ephedra) extract for many years has been used in traditional Iranian medicine for the treatment of heart problems and diabetes. The objective of this study was to determine the short- and long-term effects of this extract on weight, lipid profile, and insulin sensitivity.

Material and Method: In a randomized experimental study five groups of rats received high- calorie and high-fat diet, with 416 calorie energy per 100 grams. For three groups, Houm extract of 5, 30, and $100 \mathrm{mg}$ was started at the end of the $4^{\text {th }}$ week in the form of gavage feeding, while $150 \mathrm{mg}$ of Houm extract was given to one group in the form of acute dose. One of the groups received highcalorie and high-fat diet without intervention, while another group was the control group.

Results: Receiving Houm extract at 5, 30, and $100 \mathrm{mg}$ dose reduced the weight gain trend, while $150 \mathrm{mg}$ of Houm extract reduced weight compared to high energy diet $(306.00 \pm 57.34$ vs. $348.00 \pm 43.73$ P.value $<0.05)$. 5 and $30 \mathrm{mg}$ groups did not cause significant changes in lipid profile, blood sugar, and insulin. Further, $100 \mathrm{mg}$ dose of Houm extract reduced the cholesterol level $(56.40 \pm 6.50$ vs. $63.54 \pm 8.39$; P.value $<0.05)$ and the insulin level $(2.78 \pm 1.19$ vs. $3.90 \pm 1.45$ P.value $<0.05$ ). The acute dose of $150 \mathrm{mg}$ of Houm significantly reduced cholesterol, triglyceride, and HDL levels. In this group, insulin significantly decreased $(2.66 \pm 0.63$ vs. $3.90 \pm 1.45$ P.value $<0.05)$.

Conclusions: Houm extract could be used as a supplement to optimize lipid profile, sensitize tissues to insulin, and reduce weight in emergency cases.

Key Words: Ephedra, insulin resistance, cholesterol, rat
ÖZET

Amaç: Houm bitkisi (efedra) özü yıllardır geleneksel İran tıbbında kalp problemleri ve diyabet tedavisinde kullanılmaktadır. Bu çalışmanın amacı, bu ekstrenin ağırlık, lipid profili ve insülin duyarlılığı üzerindeki kısa ve uzun vadeli etkilerini belirlemektir.

Yöntemler: Randomize bir deneysel çalışmada, beş grup sıçan, 100 gram başına 416 kalori enerjisi ile yüksek kalorili ve yüksek yağ diyetini aldı. Üç grup için 4. hafta sonunda gavajla besleme şeklinde 5,30 ve $100 \mathrm{mg}$ Houm özü başlatılırken, bir gruba akut doz şeklinde $150 \mathrm{mg}$ Houm özü verildi. Gruplardan biri müdahalesi olmadan yüksek kalorili ve yüksek yağlı diyet alırken, diğer grup kontrol grubu idi.

Bulgular: Beş, 30 ve $100 \mathrm{mg}$ dozda Houm özü almak, kilo alma eğilimini azaltırken, $150 \mathrm{mg}$ Houm özü, yüksek enerji diyetine göre ağırlığı düşürdü $(306.00 \pm 57.34$ 'e karşılık $348.00 \pm 43.73 ; \mathrm{P}<0.05)$. 5 ve $30 \mathrm{mg}$ gruplar, lipit profilinde, kan şekeri ve insülinde önemli değişikliklere neden olmadı. Ayrıca, $100 \mathrm{mg}$ Houm ekstresi dozu kolesterol seviyesini $(56.40 \pm 6.50$ ve $63.54 \pm 8.39$; $\mathrm{P}<0.05)$ ve insülin seviyesini $(2.78 \pm 1.19$ ve $3.90 \pm 1.45 ; \mathrm{P}<0.05)$ düşürdü. 150 mg Houm'un akut dozu, kolesterol, trigliserit ve HDL seviyelerini önemli ölçüde azalttı. Bu grupta insülin anlamlı olarak azaldı ( $2.66 \pm 0.63$ vs. $3.90 \pm 1.45$; P $<0.05$ ).

Sonuç: Houm özü, lipit profilini optimize etmek, dokuları insüline duyarlı hale getirmek ve acil durumlarda ağırlığı azaltmak için bir destek olarak kullanılabilir.

Anahtar Sözcükler: Efedra, insülin direnci, kolesterol, sıçan

Geliş Tarihi: 09.04.2018

Kabul Tarihi: 12.06.2018 
Obesity is an abnormal accumulation of body fat-usually $20 \%$ or more of an individual's ideal body weight. Obesity is associated with increased risk of illness, disability, and death. The rising prevalence of obesity in the last 20-30 years has characterized as an epidemic (1). The World Health Organization (WHO) announced that obesity and its complications are among the leading health threats around the globe $(2,3)$. Physicians tend to underreport obesity and less than half of obese people are advised to lose weight, or offered a supervised diet, or exercise programmes by their doctors (4-6). These trends may encourage people seeking weight loss to respond to heavily marketed products such as nutrition supplements, many of which have limited evidence of safety or efficacy. Although numerous weight loss programmes have been developed in conventional medicine, their effectiveness has been proven to be quite limited (7).

Houm is a genus of plants found worldwide; it has a long history of use in complementary and alternative medicine (CAM). Houm is a Persian name of ephedra plant Ephedra plant has one genus and more than forty species that are scattered in different areas of the planet. The various species of Ephedra are widespread in many lands, native to southwestern North America, southern Europe, northern Africa, and southwest and central Asia, northern China, and western South America. Ephedra pachyclada species was used in this study. In traditional Chinese medicine (TCM), ephedra is called ma huang, and it is called Houm, Rish Boz, Ormak, or Alijoon in traditional Persian medicine. A major reason for using ephedra-containing herbal products is to reduce body weight. Questions of safety and efficacy are central issues for any agent used for human weight control. Ephedrine, the primary active ingredient of herbal ephedra, has been well studied both alone and in combination with caffeine. Placebo-controlled studies have demonstrated that ephedrine, particularly in combination with caffeine, is effective in promoting weight loss without triggering serious adverse events (8-10).

In the present study, the authors hypothesized that the use of herbal hydroalcoholic extract of Houm could reduce weight, improve the lipid profile of diet-induced obesity, and improve the insulin-sensitivity in rats.
Study Design

In a randomized experimental study 60 rats were randomly allocated in six groups. The concentration of ephedra in the extract was assessed. A high-fat and high-calorie diet (11) was established for five groups, and one group was the control selected. At the end of $4^{\text {th }}$ week, Houm extract was given to three groups at doses of $5 \mathrm{mg} / \mathrm{kg}, 30 \mathrm{mg} / \mathrm{kg}$, and $100 \mathrm{mg} / \mathrm{kg}$ body weight daily. At the end of $13^{\text {th }}$ week, one acute dose of $150 \mathrm{mg} / \mathrm{kg}$ was given to one other obese group. Weight, lipid profile, glucose, and insulin levels were measured at the end of $14^{\text {th }}$ week.

\section{Subjects}

Six-week-old male Wistar rats were purchased from the animal lab of Shiraz University of Medical Sciences. The rats were singly caged with free access to water and food, and they were kept on a 12:12-h light-darkness cycle. All animal procedures were approved by the local animal rights committee.

\section{Diet}

A high-calorie and high fat diet was made by the researcher. It contained $47 \%$ carbohydrate, $19 \%$ fat, and $14.5 \%$ protein by weight that was equal to $45 \%$ energy from carbohydrate, $41 \%$ from fat, and $14 \%$ from protein. The energy supplied by the diet was 416 calories per 100 grams, and the energy of standard diet was 302 calories per 100 grams. In a pilot study, the efficacy of the diet in weight gain was tested on a small group of animals.

\section{RESULTS}

\section{Weight Results}

In this study, 60 mice were used for six weeks with the mean weight of 74.65 \pm 1.6 . After the rats were randomly assigned to six groups, a high-energy and high-fat diet was considered for five groups and one group was the control. The rats' weights were at the baseline between the groups and did not differ significantly $(p=0.299)$ (Table 1$)$.

Table 1. Weight values in various groups over time.

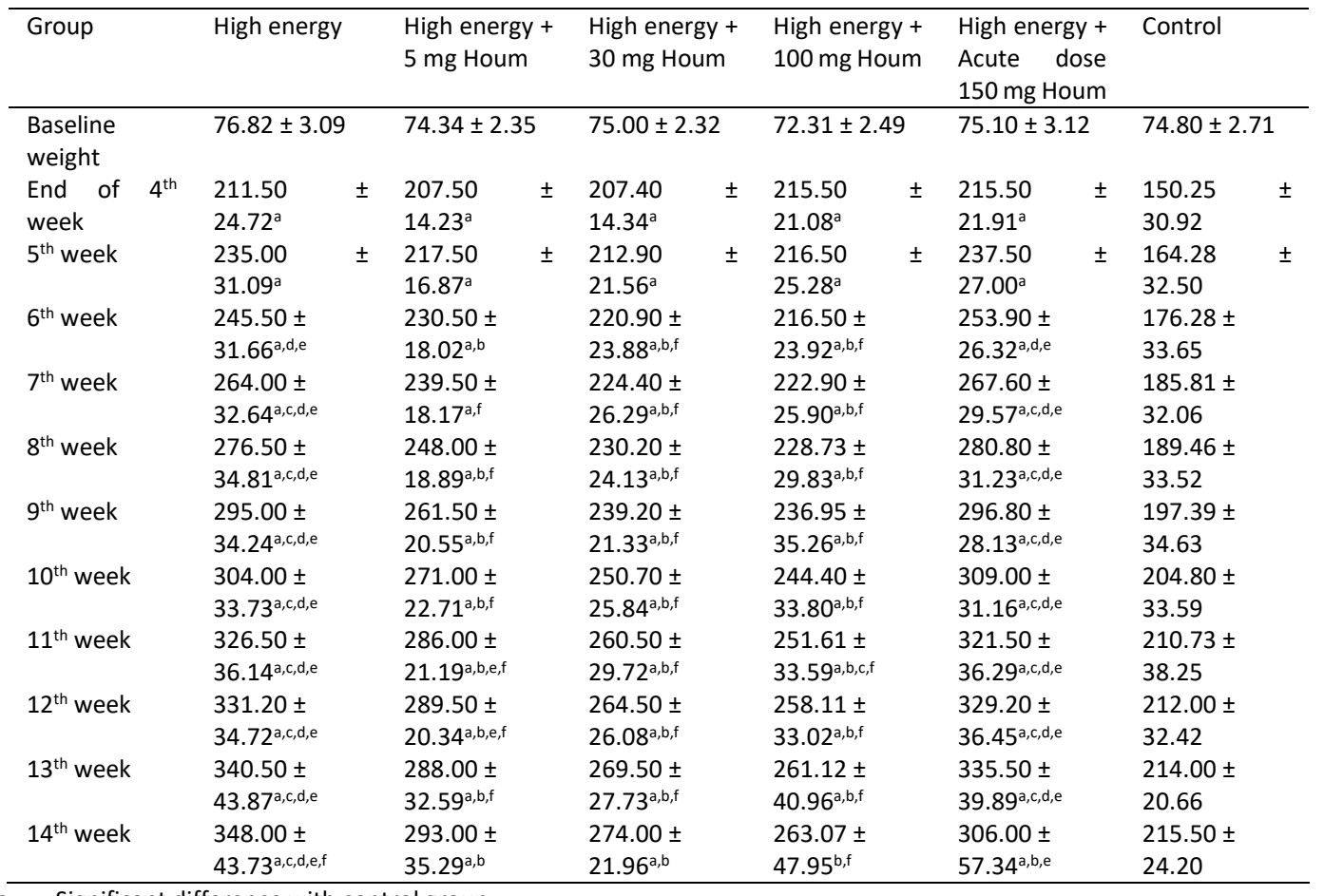

a. Significant difference with control group.

b. Significant difference with High energy group.

c. Significant difference with $5 \mathrm{mg}$ Houm.

d. Significant difference with $30 \mathrm{mg}$ Houm.

e. Significant difference with $100 \mathrm{mg}$ Houm.

f. Significant difference with Acute dose group. 
Four weeks of high-energy diet significantly increased weight in high-fat diet compared with the control group $(211.48 \pm 19.24$ vs. $150.25 \pm 30.92$; P value $<0.001)$. In this stage, three groups out of the five groups receiving highenergy regime started intervention of hydro-alcoholic extract Houm with doses of 5, 30, and $100 \mathrm{mg}$ in the form of gavage feeding. Meanwhile, the groups continued the programme according to their prior diet. Houm consumption of $5 \mathrm{mg}$ of hydro-alcoholic extract reduced the weight gain trend so that after two weeks of taking the extract, their weight difference from that of the high-energy diet group, which did not receive the extract, was significant ( $230.50 \pm 18.17$ vs. $245.50 \pm 31.66$; $P$ value $<0.05$ )
This significant difference in weight was also observed after two weeks in other groups that received higher doses of Houm extract $(220.90 \pm 23.88$ and 216.50 \pm 23.92$)$. Weight differences between the groups receiving different doses of Houm extract were visible in the diagram (Figure 1). However, it was not significant. The trend of weight gain in the groups that consumed different doses of Houm extract was slower than the one with high-energy consumption, but there was no difference between different doses until the $12^{\text {th }}$ week. At the beginning of the $12^{\text {th }}$ week, the consumer group of $5 \mathrm{mg}$ of Houm extract had no significant weight difference with the consumer group of $100 \mathrm{mg}$ ( $251.61 \pm 33.59$ vs. $286.00 \pm 21.19$; $\mathrm{P}$ value<0.05). Weight difference remained significant for two weeks, but the difference disappeared later.

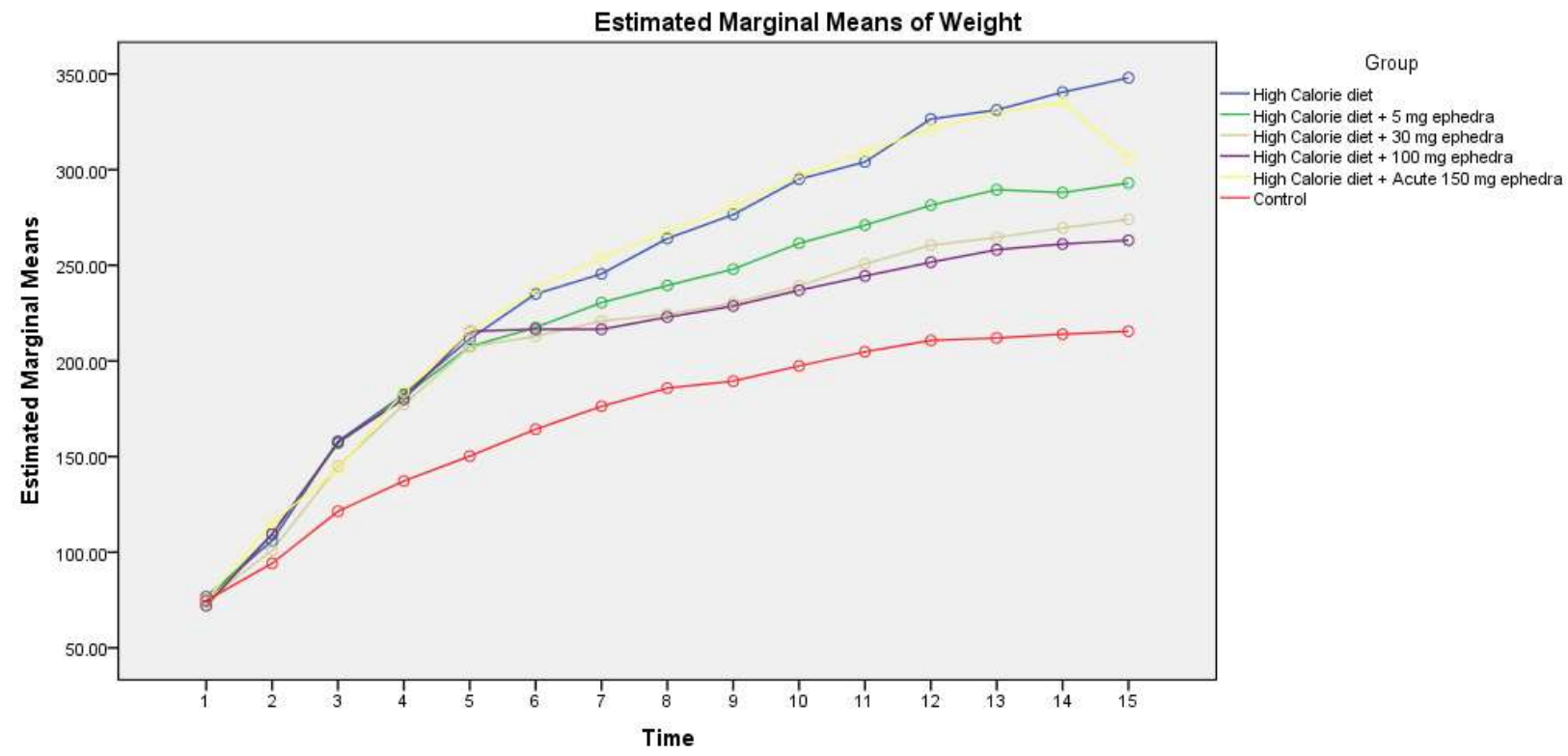

Figure 1. Weight change trends in various groups

At the beginning of the $14^{\text {th }}$ week for another group, Houm extract as a single dose of $150 \mathrm{mg}$ was used, which caused significant weight loss compared with the group consuming the high-energy diet $(306.00 \pm 57.34$ vs. $348.00 \pm 43.73 P$ value $<0.05)$

\section{Results of Lipid Profile}

The high energy and high-fat diet increased cholesterol $(63.54 \pm 8.39$ vs. $53.04 \pm 8.30 ; P$ value $<0.05)$ and triglycerides levels ( $115.03 \pm 45.69$ vs. $82.67 \pm$ 32.58; $P$ value<0.05). HDL levels between the two groups did not differ significantly (35.94 \pm 6.77 vs. $32.09 \pm 7.70 ; P$ value $=0.127$ ) (Table 2 ).

Houm in the $5 \mathrm{mg}$ dose of hydro-alcoholic extract did not cause any significant difference in cholesterol, triglycerides, and HDL, compared to the high-fat group and high energy group. Even for cholesterol, this group was significantly higher than the control group (63.89 \pm 7.34 vs. $53.04 \pm 8.30 ; P$ value<0.05)

In the $30 \mathrm{mg}$ Houm consumer group, despite the decrease in cholesterol and triglyceride levels, no significant differences were found compared to controls or a high-fat and high- energy diet.

However, cholesterol levels decreased significantly in the $100 \mathrm{mg}$ Houm consumer group ( $56.40 \pm 6.50$ vs. $63.54 \pm 8.39$; $P$ value $<0.05)$.
In case of triglyceride, despite the reduction levels compared to the group consuming high-fat and the high energy diet, no significant difference was seen. This group also showed a significant decrease in HDL levels $(29.98 \pm 3.81$ vs. 35.94 \pm 6.77 ; $P$ value $<0.05$ )

The single-dose group consuming $150 \mathrm{mg}$ of Houm showed a significant reduction in cholesterol, triglyceride, and $\mathrm{HDL}$, thereby indicating the ability to improve lipid profile in the short-term by Houm

\section{Sugar and Insulin Results}

The high-energy and high-fat diet increased blood sugar and insulin levels, which could be an indicator of insulin resistance and confirm it as a low Quicki index. Houm extract consumption with the ability of reducing blood sugar was not able to demonstrate significant results, while doses of $100 \mathrm{mg}$ and $150 \mathrm{mg}$ of Houm could significantly reduce insulin $(2.78 \pm 1.19$ and $2.66 \pm 0.63$ vs. 3.90 \pm 1.45 with $P$ value $<0.05$, respectively). The Quicki index showed no significant difference.

Eliminating the effect of weight loss in the ANCOVA model and administrating Houm could not show a significant impact on glucose or insulin levels, suggesting the indirect effect by reducing weight and not by increasing the cell sensitivity to insulin and glucose. 
Table 2. Metabolic values in various groups over time.

\begin{tabular}{lllllll}
\hline Group & High energy & $\begin{array}{l}\text { High energy }+ \\
5 \mathrm{mg} \mathrm{Houm}\end{array}$ & $\begin{array}{l}\text { High energy }+ \\
30 \mathrm{mg} \text { Houm }\end{array}$ & $\begin{array}{l}\text { High energy }+ \\
100 \mathrm{mg} \text { Houm }\end{array}$ & $\begin{array}{l}\text { High energy } \\
+ \text { Acute } \\
\text { dose } \\
\text { dontrol }\end{array}$ \\
\hline Cholesterol & $63.54 \pm$ & $63.89 \pm$ & $57.95 \pm$ & $56.40 \pm$ & $50.09 \pm$ & $53.04 \pm$ \\
& $8.39^{\mathrm{a}, \mathrm{e}, \mathrm{f}}$ & $7.34^{\mathrm{a}, \mathrm{e}, \mathrm{f}}$ & $9.01^{\mathrm{f}}$ & $6.50^{\mathrm{b}, \mathrm{c}}$ & $6.76^{\mathrm{b}, \mathrm{c}, \mathrm{d}}$ & $8.30^{\mathrm{b}, \mathrm{c}}$ \\
Triglyceride & $115.03 \pm$ & $104.40 \pm$ & $91.73 \pm$ & $86.83 \pm$ & $85.33 \pm$ & $82.67 \pm$ \\
& $45.69^{\mathrm{a}, \mathrm{e}}$ & 33.74 & 31.72 & 10.92 & $27.63^{\mathrm{b}}$ & $32.58^{\mathrm{b}}$ \\
HDL & $35.94 \pm$ & $33.85 \pm$ & $33.79 \pm$ & $29.98 \pm$ & $28.65 \pm$ & $32.09 \pm$ \\
Glucose & $6.77^{\mathrm{e}, \mathrm{f}}$ & $4.96^{\mathrm{f}}$ & $4.97^{\mathrm{f}}$ & $3.81^{\mathrm{b}}$ & $3.97^{\mathrm{b}, \mathrm{c}, \mathrm{d}}$ & 7.70 \\
& $184.29 \pm$ & $177.95 \pm$ & $176.02 \pm$ & $174.27 \pm$ & $164.29 \pm$ & $168.25 \pm$ \\
Insulin & 50.92 & 21.45 & 40.37 & 18.72 & 13.53 & 14.91 \\
& $3.90 \pm$ & $3.00 \pm$ & $2.93 \pm$ & $2.78 \pm$ & $2.66 \pm$ & $2.75 \pm$ \\
Quicki index & $1.45^{\mathrm{a}, \mathrm{e}, \mathrm{f}}$ & 1.50 & 1.49 & $1.19^{\mathrm{b}}$ & $0.63^{\mathrm{b}}$ & $0.57^{\mathrm{b}}$ \\
\hline
\end{tabular}

\footnotetext{
a. Significant difference with control group.

b. Significant difference with High energy group.

c. Significant difference with $5 \mathrm{mg}$ Houm.

d. Significant difference with $30 \mathrm{mg}$ Houm.

e. Significant difference with 100mg Houm.

f. Significant difference with Acute dose group.
}

\section{DISCUSSION}

The main purpose of the present study was to prove that Houm extract has anti-obesity and anti-diabetic effects. In this study, it was observed that Houm with various doses could reduce the weight gain trend and improve insulin sensitivity and lipid profile.

Houm belongs to the ephedra family and contains alkaloids composition of ephedrine and pseudoephedrine. The main component of ephedrine has been called an 'energizer' for stimulating central the nervous system and the heart by increasing the heart rate and often elevating blood pressure. Although its anti-obesity effect through fat-burning and appetite-suppression is not fully approved, it is a common ingredient in many weight-loss and energyenhancing products $(12,13)$. There is no considerable study on the antidiabetic effect of ephedra and the ability of improving insulin sensitivity. One study reports that insulin sensitivity was improved after consumption of the supplement containing ephedra. However, it points out that this process might take place as a consequence of weight reduction $(6,14)$.

Several sympathomimetic agents have been tried to elucidate their pharmacological mechanisms in terms of weight loss. Sibutramine (15), phenylpropanolamine (16), and phentermine (17) have been tried for assessing weight-reducing effects. In a clinical trial with ephedra, Vukovich demonstrated that an acute dose of the herb, combined with caffeine, increased the resting energy expenditure (REE) by $8.5 \%$ compared to the placebo trial (18). However, the author emphasized that albeit significant, the increase in energy expenditure was negligible in terms of weight loss. Another study by Greenway also showed that $8 \%$ of RMR increase in an ephedra with the caffeine group when measured after $2 \mathrm{~h}$ of administration (19). Beyond the acute effect, there was Astrup's study(20). The ephedra with the caffeine group showed significantly less decrease of 24-h energy expenditure and weight loss compared to the placebo after eight weeks of an energy restricted diet.

In the literature, ephedrine has been used for two reasons: weight reduction and athletic performance. This research focused on this compound's weight reduction effect. Astrup et al. (20) studied the effect of ephedrine and caffeine versus placebo on body composition. Fourteen obese women were treated with a 4.2-MJ/d diet and with either Ephedrine and Caffeine $(\mathrm{E}+\mathrm{C})$ or placebo (P) three times a day (60 $\mathrm{mg}$ of ephedrine and $600 \mathrm{mg}$ of caffeine) for eight weeks in a double-blind study. Weight-loss was not different in the groups, but the $E+C$ group lost $4.5 \mathrm{~kg}$ more body fat and $2.8 \mathrm{~kg}$ less fat-free mass (FFM).

Boozer et al. (21) examined the effect of weight loss of in terms of the herbal Ma Huang and Kola nut supplement (90/192 mg/day ephedrine alkaloids/caffeine), reporting that herbal versus placebo treatment decreased body weight $(-5.3+/-5.0$ vs. $-2.6+/-3.2 \mathrm{~kg}, \mathrm{P}<0.001)$, body fat $(-4.3+/-3.3 \mathrm{vs}$. $2.7+/-2.8 \mathrm{~kg}, P=0.020)$, and LDL-cholesterol $(-8+/-20$ vs. $0+/-17 \mathrm{mg} / \mathrm{dl}$, $P=0.013)$, while it increased HDL-cholesterol $(+2.7+/-5.7$ vs. $-0.3+/-6.7 \mathrm{mg} / \mathrm{dl}$, $\mathrm{P}=0.004)$.

Alman et al. (22) determined the effects of ephedrine on body mass, body composition, metabolic variables, and mood states in healthy overweight adults. The experimental group $(n=16)$ received a capsule containing $20 \mathrm{mg}$ of ephedrine alkaloids, $5 \mathrm{mg}$ of synephrine, $200 \mathrm{mg}$ of caffeine and $15 \mathrm{mg}$ of salicin twice every day for eight weeks, whereas the other group $(n=14)$ received a matching placebo.
The experimental group had a significantly greater weight loss compared to that by the placebo group ( $3.14 \mathrm{~kg}$ vs. $2.05 \mathrm{~kg}, \mathrm{P}<0.05)$. The experimental group experienced $16 \%$ decrease in body fat compared to the $1 \%$ increase for the placebo group.

In the most similar study to the present one, Malecka-Tendera(23) studied the effect of ephedrine $(E)$ and theophylline $(T)$, both administered alone and in combination $(E / T)$, on weight loss, resting energy expenditure, and postheparin lipoprotein lipase activity in plasma (PHLA) as well as in adipose tissue (ATLP) in obese over-fed rats. She reported that E, T, and E/T significantly increased weight loss in all the experimental groups compared to the controls. The effect of the E/T mixture was no greater than that of E or T alone. Serum cholesterol levels were not influenced by hypocaloric diet and drug administration. However, serum triglycerides increased significantly in $E, T$, and $\mathrm{E} / \mathrm{T}$-treated groups.

In this study, different doses of Houm extract showed a negative impact on the weight gain trend; this effect was clearly dose-dependent and slower weight gain was seen with higher doses of Houm. But this difference was not very significant. Especially noteworthy is the long-term impact of Houm, which stated its inability in keeping weight reduction for several weeks-the weight gain trend stopped, but afterwards the rhythm, though slower, began to increase. Thus, this treatment cannot be used for long-term weight loss but, in short-term emergencies it can be used temporarily to reduce weight.

\section{CONCLUSIONS}

The decreases in total and LDL cholesterol as well as triglyceride levels indicate that these risk factors were improved for atherosclerosis and other cardiovascular morbidity/mortality in conjunction with the weight loss induced by the treatment. Similarly, the decreases in fasting glucose, insulin, and the Quicki index observed after weight loss in the treatment groups indicate that insulin sensitivity has improved been. An effect that would be expected to decrease the risks of impaired glucose intolerance, metabolic syndrome, and Type-2 diabetes associated with obesity. But unfortunately, after adjusting for weight changes, this difference was not significant in the ANCOVA model, which suggested the Houm extract impact on blood glucose, insulin, and lipid profile owing to the ability to lose weight. The point which should be considered is the influence of extract on HDL, which was unfortunately reduced and was a negative point in terms of the ability to lose weight and improve health.

\section{Acknowledgment}

Funding for this project was sponsored by Fasa University of Medical Sciences (Code: 89034).

Conflict of interest

No conflict of interest was declared by the authors. 


\section{REFERENCES}

1.Babai, M.A., et al., Defining a BMI cut-off point for the Iranian population: the Shiraz Heart Study. PLoS One, 2016. 11: p. e0160639.

2.Despres, J., Intra-abdominal obesity: an untreated risk factor for Type 2 diabetes and cardiovascular disease. Journal of endocrinological investigation, 2006; 29: 77.

3.Zand, H., et al., Obesity-induced p53 activation in insulin-dependent and independent tissues is inhibited by beta-adrenergic agonist in diet-induced obese rats. Life sciences, 2016; 147: 103-9.

4.Stafford, R.S., et al., National patterns of physician activities related to obesity management. Archives of family medicine, 2000; 9: 631.

5.Wadden, T.A., et al., Obese women's perceptions of their physicians' weight management attitudes and practices. Archives of family medicine, 2000; 9: 854-62.

6. Homayounfar, R., et al., Relationship of p53 accumulation in peripheral tissues of high-fat diet-induced obese rats with decrease in metabolic and oncogenic signaling of insulin. General and comparative endocrinology, 2015; 214:134-9.

7.Márquez, F., et al., Evaluation of the safety and efficacy of hydroxycitric acid or Garcinia cambogia extracts in humans. Critical reviews in food science and nutrition, 2012; 52: 585-94.

8.Shekelle, P.G., et al., Efficacy and safety of ephedra and ephedrine for weight loss and athletic performance: a meta-analysis. Jama, 2003; 289: 1537-45.

9.Kim, B.-S., M.-y. Song, and H. Kim, The anti-obesity effect of Ephedra sinica through modulation of gut microbiota in obese Korean women. Journal of ethnopharmacology, 2014; 152: 532-9.

10.Yen, M. and M.B. Ewald, Toxicity of weight loss agents. Journal of medical toxicology, 2012; 8: 145-52.

11.Ehrampoush, E., et al., Ability of dairy fat in inducing metabolic syndrome in rats. SpringerPlus, 2016; 5: 2020.

12.Bent, S., et al., The relative safety of ephedra compared with other herbal products. Annals of internal medicine, 2003; 138: 468-71.
13. Rotblatt, M., Herbal medicine: expanded commission E monographs. Annals of internal medicine, 2000; 133: 487-87.

14. Hackman, R., et al., Multinutrient supplement containing ephedra and caffeine causes weight loss and improves metabolic risk factors in obese women: a randomized controlled trial. International journal of obesity, 2006; 30: $1545-56$

15. Hirsch, J., R.M. Mackintosh, and L.J. Aronne, The Effects of Drugs Used to Treat Obesity on the Autonomic Nervous System\&ast. Obesity, 2000; 8:22733.

16.Krentz, A., K. Fujioka, and M. Hompesch, Evolution of pharmacological obesity treatments: focus on adverse side-effect profiles. Diabetes, Obesity and Metabolism, 2016; 18: 558-70.

17.Patel, D.K. and F.C. Stanford, Safety and tolerability of new-generation antiobesity medications: a narrative review. Postgraduate medicine, 2018; 130 173-82.

18.Vukovich, M.D., et al., Caffeine-herbal ephedra combination increases resting energy expenditure, heart rate and blood pressure. Clinical and experimental pharmacology and physiology, 2005; 32: 47-53.

19.Greenway, F.L., et al., Effect of a Dietary Herbal Supplement Containing Caffeine and Ephedra on Weight, Metabolic Rate, and Body Composition\&ast; \&ast. Obesity, 2004; 12: 1152-7.

20.Astrup, A., et al., The effect of ephedrine/caffeine mixture on energy expenditure and body composition in obese women. Metabolism, 1992; 41: 686-8.

21.Boozer, C., et al., Herbal ephedra/caffeine for weight loss: a 6-month randomized safety and efficacy trial. International journal of obesity and related metabolic disorders: journal of the International Association for the Study of Obesity, 2002; 26: 593.

22.Kalman, D.S., et al., Effects of a weight-loss aid in healthy overweight adults: double-blind, placebo-controlled clinical trial. Current Therapeutic Research, 2000; 61:199-205.

23.Malecka-Tendera, E., Effect of ephedrine and theophylline on weight loss, resting energy expenditure and lipoprotein lipase activity in obese over-fed rats. International journal of obesity, 1993; 17: 343-7. 